\title{
Population biology and ecology of the endangered Euphorbia susannae Marloth, an endemic to the Little Karoo, South Africa
}

\author{
LAAIQAH JABAR ${ }^{1, \boldsymbol{v}}$, STEFAN JOHN SIEBERT ${ }^{2}$, MICHÈLE FRANZISKA PFAB ${ }^{3}$, \\ DIRK PETRUS CILLIERS \\ ${ }^{1}$ National Department of Forestry, Fisheries and the Environment. 473 Steve Biko Road, Arcadia, Pretoria 0083, South Africa. Tel. +27-66-169-5794, \\ vemail: LJabar@environment.gov.za \\ ${ }^{2}$ Unit for Environmental Sciences and Management, Faculty of Natural and Agricultural Sciences, North-West University. Potchefstroom Campus, \\ Hoffman Street 11, Potchefstroom 2531, South Africa \\ ${ }^{3}$ South African National Biodiversity Institute, Pretoria National Botanical Garden. 2 Cussonia Avenue, Brummeria, Pretoria 0184, South Africa
}

Manuscript received: 13 September 2021. Revision accepted: 28 September 2021

\begin{abstract}
Jabar L, Siebert SJ, Pfab MF, Cilliers DP. 2021. Population biology and ecology of the endangered Euphorbia susannae Marloth, an endemic to the Little Karoo, South Africa. Biodiversitas 22: 4583-4596. Many euphorbias in the semi-arid parts of South Africa are restricted edaphic specialists with small populations at risk of extinction. Euphorbia susannae is one such species, which grows on the edges of quartz patches along a section of the northern foot slopes of the Langeberg Mountains. This study set out to acquire data on the biology and ecology of the species during a first-ever comprehensive field survey. The resultant dataset allowed for the determination of the geographic distribution of the species, as well as the size and number of populations. Biotic and abiotic environmental variables were employed to generate a habitat profile and a species distribution model. The population structure, regeneration potential, and stability of each subpopulation and the population were also assessed. Euphorbia susannae is a rangerestricted species (EOO $170 \mathrm{~km} 2$ and AOO $36 \mathrm{~km} 2$ ) confined to eight subpopulations that vary considerably in size. According to this study, 1845 individuals remain in the wild. Habitat preferences of the species were considered in detail and linked to a species distribution model for conservation purposes. It was shown that the species preferred nurse plants. The smallest adults size class was the largest cohort in all the sub-populations and was ascribed to pulse recruitments after an unknown favorable event. Although individuals were not evenly distributed among the size classes, annual recruitments levels were healthy, suggesting good pollination, seed set, and germination conditions.
\end{abstract}

Keywords: Conservation, edaphic specialist, endemism, Euphorbiaceae, Succulent Karoo Biome, quartz patches, Western Cape

Abbreviations: AOO: Area of Occupancy; EOO: Extent of Occurrence

\section{INTRODUCTION}

There appears to be a general lack of information on the biology and ecology of succulent euphorbias in southern Africa. Many studies focused on species indigenous to the sub-tropical parts of South Africa (Pfab and Witkowski 1999; Van der Linde et al. 2017). No quantitative studies have been conducted on the locally endemic euphorbias of the arid and semi-arid parts of the winter rainfall region of South Africa.

The charismatic and well-known Euphorbia susannae Marloth is endemic to the Little Karoo (Vlok and SchutteVlok 2015) of the Western Cape Province of South Africa. While the foremost threat to the survival of the plants inhabiting this region is habitat destruction and climate change (Young et al. 2016), the unsustainable harvest of wild succulents for the horticultural trade may place additional pressure on populations of rare and endemic taxa which are already at risk of extinction (CITES 2012). As a result, Euphorbia susannae is a popular subject in specialist plant collections around the world (Bertetti et al. 2012), and international trade in the species is regulated through its inclusion in Appendix II to the Convention on
International Trade in Endangered Species of Wild Fauna and Flora (CITES).

Euphorbia susannae is currently listed as Endangered B1ab(iii,v)+2ab(iii,v) on the Red List of South African plants, due to the extent of Occurrence (EOO) of $290 \mathrm{~km}^{2}$, an Area of Occupancy (AOO) of $<290 \mathrm{~km}^{2}$ and four known locations (Vlok and Raimondo 2007). The term 'location', in this sense, is defined as a geographically or ecologically distinct area in which a single threatening event can rapidly affect all individuals of the taxon present (IUCN 2016). Recorded threats to the species include illegal harvest and habitat degradation due to overgrazing and trampling (Vlok and Raimondo 2007).

CITES necessitates that trade in Appendix II species is sustainable. Consequently, countries exporting plant species listed in Appendix II are required to demonstrate that the export levels are not detrimental to the survival of the species concerned or to their role within the ecosystems in which they occur (Smith et al. 2011). This is achieved through the compilation and issuing of a Non-Detriment Finding (NDF) by the Scientific Authority of the country concerned. An NDF is a science-based risk analysis in which the vulnerability of a species (i.e., extrinsic and 
intrinsic factors that increase extinction risk) is weighed against how well it is managed (Smith et al. 2011). Factors such as the biological and ecological characteristics of the species, its national status (distribution, abundance, and threats), protection of the species from harvest, and trade information relating to the species are considered (SANBI 2014). Data presented in such a review should be recent and quantitative to enhance the confidence in the assessment (Smith et al. 2011).

This study aimed to generate current, reliable information on the population biology and ecology of $E$. susannae. To achieve this, the following specific research objectives were addressed: (i) to ascertain the geographic distribution and plant abundance as well as the number of populations; (ii) to determine the habitat profile of the species; and (iii) to elucidate the population structure, regeneration potential and dispersal efficiency of populations. The study ultimately aims to provide insight into the species' population dynamics, valuable information for predicting how populations respond to climate change, habitat degradation, or harvest. Furthermore, it is anticipated that the study will contribute significantly to our knowledge and understanding of succulent euphorbias in arid southern African ecosystems and prove a valuable addition to the relatively limited body of literature on CITES-listed succulent plants.

\section{MATERIALS AND METHODS}

\section{Species}

Euphorbia susannae is a perennial, spineless dwarf succulent. Young plants consist of a single spherical 12 to 16-angled main stem and a caudex, with the majority of the plant sunken beneath the ground. With age, the main stem produces numerous globose or globose-cylindrical branches (which may themselves rebranch with age) (Figure 1.A), leading to the formation of a compact rosette (Court 2010; Vlok and Schutte-Vlok 2015). Growth is apical and upward, but the stems are dragged downwards by contractile action in the roots (Court 2010). Tubercles are prominent, elongated, and narrowly triangular (Figure 1.B) and maybe recurved or straight. Leaves are reduced to tiny bristle-like hairs projecting from the tips of young tubercles (Figure 1.B) but are soon abscised. This species is dioecious (bearing male and female flowers on separate plants) and flowers from April to July (Jabar 2019). Staminate cyathia of the male plant (Figure 1.C) are carried on peduncles arising from the axils of the tubercles. Pistillate cyathia of the female plant are sessile between the apical tubercles and possess styles with bifid tips (Figure 1.D). Glands of pistillate and staminate cyathia are yellowgreen to brownish, nearly contiguous, and transversely oblong with entire margins. The seed capsules are trilocular, glabrous, and dark purple at maturity (Figure 1.E).

\section{Study area}

Euphorbia susannae occurs in the Little Karoo (Figure 2) - an arid intermontane valley in the Western Cape, South Africa, which falls within the Rainshadow Valley Karoo Bioregion (Mucina et al. 2006) of the Succulent Karoo Biome. Two parallel mountain chains border the area - the Swartberg to the north and the Langeberg and Outeniqua Mountains in the south (Van Wyk and Smith 2001) and are approximately $23,500 \mathrm{~km} 2$ in extent.
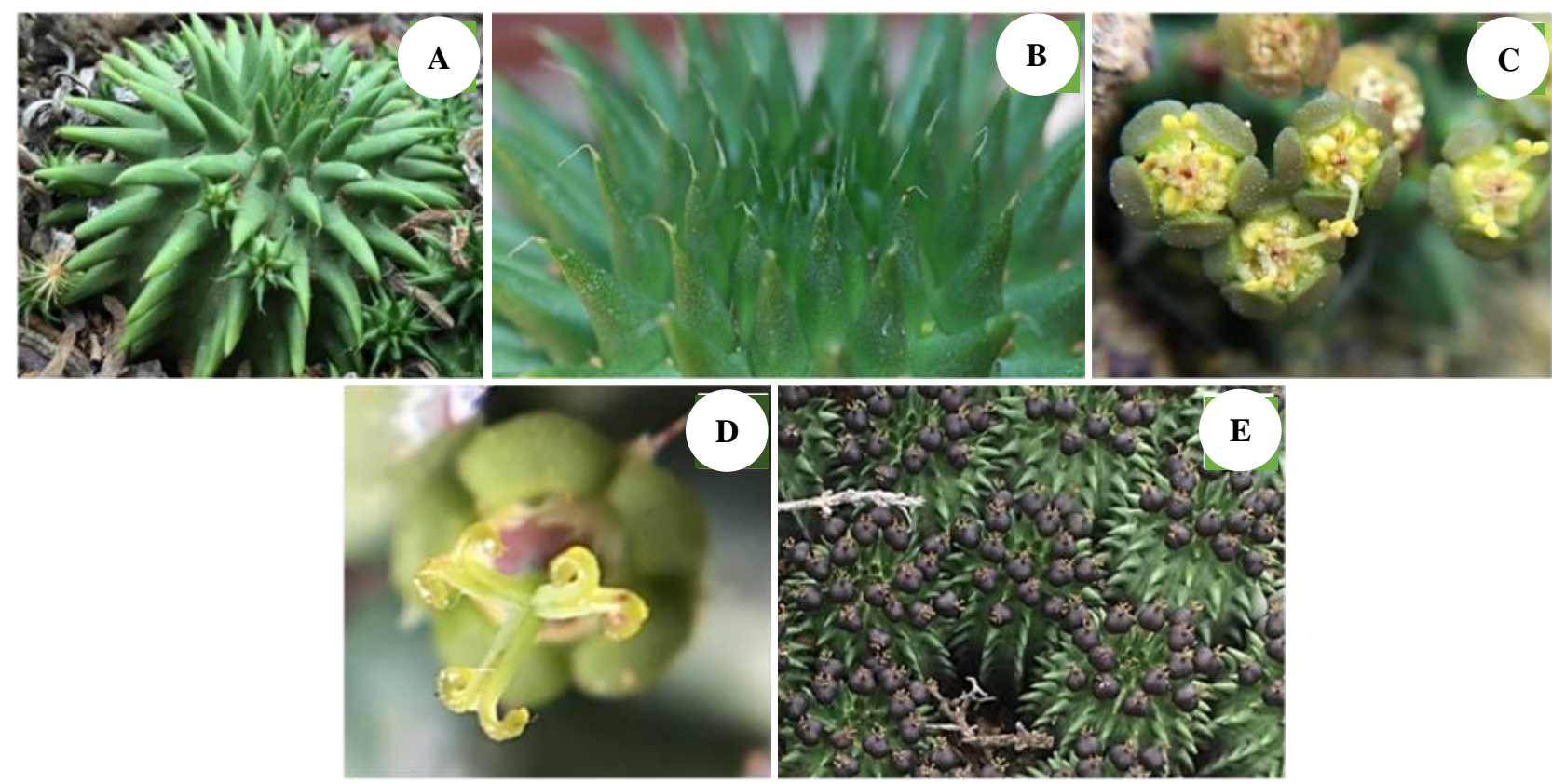

Figure 1. Euphorbia susannae: A. Main stem of sub-adult plant beginning to sprout young stems; B. Highly reduced, hair-like leaves on the tips of new tubercles; C. Staminate cyathia of a male plant; D. Bifid style tips of pistillate cyathium of a female plant; E. Globose branches bearing mature fruits on a female plant 

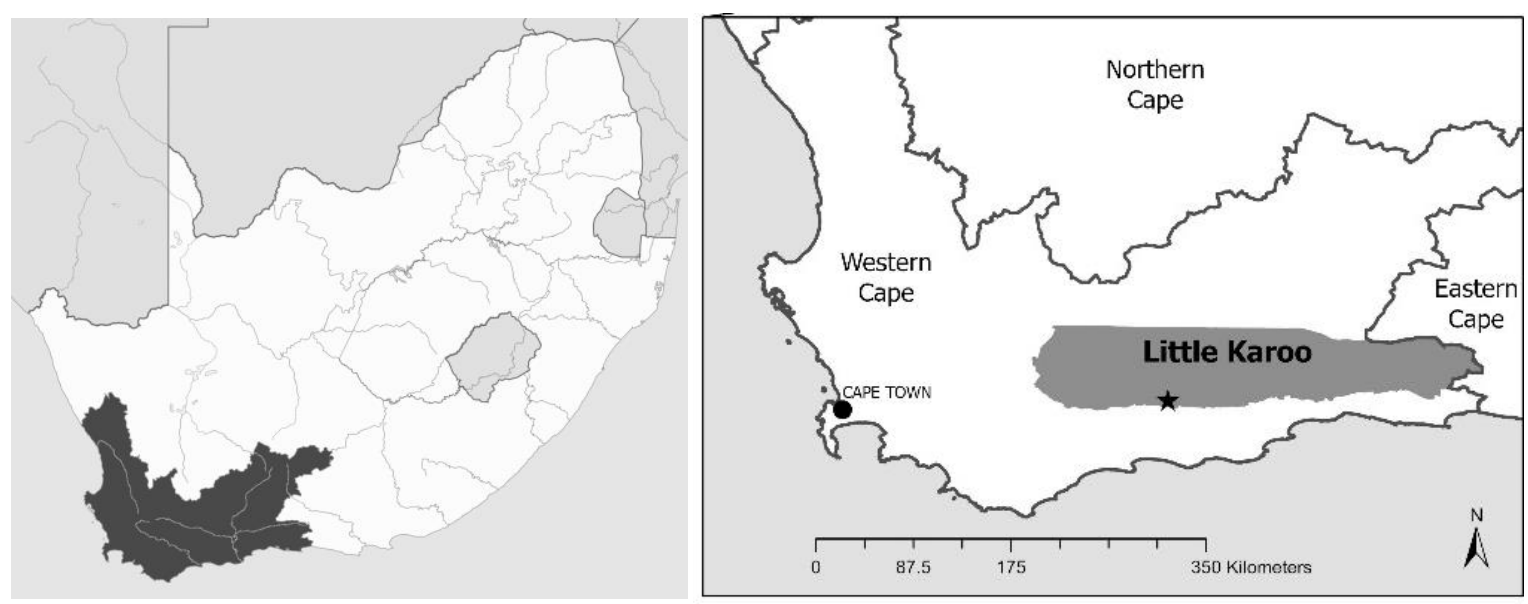

Figure 2. Location of the study area in the Western Cape, South Africa (Euphorbia susannae distribution indicated by star)

Several isolated, minor mountain ranges rise from the valley floor, and one of those, the Rooiberg range, divides the Little Karoo into eastern and western portions (Vlok and Schutte-Vlok 2015). The west landscape, wherein $E$. susannae occurs, comprises flat plains, undulating hills, rocky ridges, arid mountain foothills, and slopes. The dry plains, foothills, and lower slopes of the mountains (which rise 1500-2000 m above sea level) harbor the Little Karoo Quartz Vygieveld vegetation unit, which is floristically of a Succulent Karoo affinity, often grading into Montagu Shale Renosterveld where the rainfall is higher, while Fynbos occurs at higher altitudes on the mountains (Mucina et al. 2006).

A distinctive feature of the Succulent Karoo Biome is the highly predictable seasonal and interannual rainfall regime. It provides an element of climatic stability that plays an essential role in fostering and sustaining species diversity (Mucina et al. 2006). Although the Little Karoo receives a higher proportion of precipitation than the rest of the biome, it is still arid, owing mainly to the rain-shadow effect produced by the Langeberg in the south. The western Little Karoo receives predominantly cyclonic winter rain from May to September (Van Wyk and Smith 2001). The mean annual rainfall varies between 230 and $420 \mathrm{~mm}$ per annum, and the mean yearly temperature is $15.6-16{ }^{\circ} \mathrm{C}$ (Mucina et al. 2006). Huge diurnal and seasonal temperature fluctuations are a distinguishing characteristic of the Little Karoo, and differences of up to $28{ }^{\circ} \mathrm{C}$ between night and day are not unusual in the lowlands (Van Wyk and Smith 2001).

Succulent Karoo vegetation in the Little Karoo occurs predominantly on shales of the Bokkeveld Group (Cape Supergroup), with other rocks of the Supergroup, e.g., conglomerate, siltstone, and quartzite, playing a lesser role in certain areas (Mucina et al. 2006). Scree borders the mountain chains, while major river channels are surrounded by alluvium. Soils in the valleys are derived chiefly from shales and conglomerates and are predominantly shallow and stony (Van Wyk and Smith 2001).

\section{Locating populations}

Euphorbia susannae prefers soils characterized by desert pavement formed by a layer of gravel and stones. Where weathered quartz veins accompany the shales, localized fields of white desert pavement, termed quartz patches, occur. This ground cover not only acts as a protective mulch, reducing raindrop impact and enhancing water infiltration, but the reflective property of the white quartz also lowers the surface temperature of the soil (Curtis et al. 2013).

Details of known sites were acquired from locality records obtained from the National (PRE) and Bolus (BOL) herbaria, from Cape Nature (the agency in charge of Western Cape's nature conservation), and the South African National Biodiversity Institute's Custodians of Rare \& Endangered Wildflowers program (CREW). Experts on the area's flora, conservation officials, landowners, nursery owners, and succulent enthusiasts provided additional locality data. Locality data were also obtained from iSpot (www.ispotnature.org/communities/southernafrica), a citizen science platform (citizen observatory) to document biodiversity. Field surveys targeted these areas, but finding populations was often hampered by vague and outdated locality references. For example, one locality could not be assessed due to the refusal of a grant of access by the landowner. Surveys were conducted to coincide with anticipated flowering and fruiting times (Table 1).

Table 1. Dates on which surveys were conducted for Euphorbia susannae and the reproductive state of plants found at the study.

\begin{tabular}{llll}
\hline & Autumn & Winter & Spring \\
\hline $\begin{array}{l}\text { Survey date } \\
\text { Observed }\end{array}$ & 20-26 May & 6-10 July & 6-10 October \\
phenological & underway, & Very few & $\begin{array}{l}\text { Some fruits are } \\
\text { still present, } \\
\text { state of }\end{array}$ \\
plants & some fruits & $\begin{array}{l}\text { cyathia left, } \\
\text { fruits present. }\end{array}$ & $\begin{array}{l}\text { and dispersal is } \\
\text { underway. }\end{array}$ \\
\hline
\end{tabular}




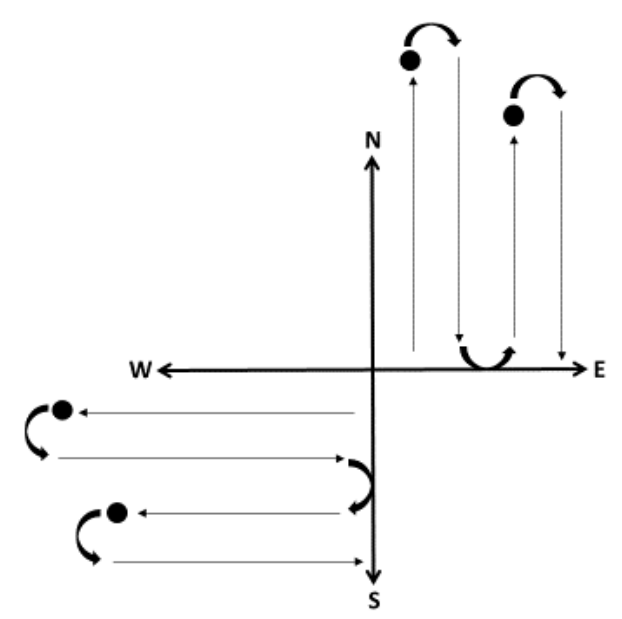

Figure 3. Diagrammatic representation of the systematic search method employed for conducting total counts of Euphorbia susannae

\section{Population delineation, size, and density}

As E. susannae is considered Endangered (Vlok and Raimondo 2007), and population sizes were thus expected to be minor, it was decided that total counts would be carried out. Therefore, three tasks were conducted concurrently during surveys.

A conspicuous marker was placed at the first plant found at a locality. The area was divided into four quadrants, with the marker as the center point. Ropes were laid to serve as North-South and East-West axes. Each quadrat was systematically searched for plants by two people traversing meter-wide transects in a direction parallel to the slope of each site, working from the marker outwards, and then doubling around at the point where no more individuals could be found to traverse the adjacent transect (Figure 3).

Plants of $E$. susannae were patchily distributed, most probably due to the ballistic mode of seed dispersal. This mode of dispersal results in parents and offspring occurring in relative proximity. Therefore, Pfab and Witkowski (1999) indicated that sampling plant attributes from certain areas within Euphorbia populations should result in a realistic sample of the entire population regarding the distribution of stages and sizes. Plants in two opposing quadrants (Figure 3) were measured for several attributes until a sample of $\mathrm{n}=40$ for each was reached per quadrat (total of $\mathrm{n}=80$ for the site). All subsequent individuals found were counted only. Markers were placed to avoid recounting/resampling.

GPS coordinates were taken at the outermost plant found per quadrat to map the edges of the population so that the area occupied (area coverage of the population) could be calculated.

The equation used to calculate density was No. of individuals/Area occupied 'in ha'.

\section{Plant measurements and observations}

The size of each plant sampled was quantified in two ways. First, the number of stems was counted, and the widest diameter of the area covered by the plant (W1) and the diameter perpendicular to this (W2) was measured to calculate canopy area using the following equation (Pfab and Witkowski 1999):

$$
\begin{aligned}
\text { Canopy area } & =\pi \times \frac{W 1}{2} \times \frac{W 2}{2} \\
& =0.7854 \times W 1 \times W 2
\end{aligned}
$$

The number of cyathia and fruits on each plant were counted if present, and notes were taken on the male or female sex status of the plant. Dead plants encountered while sampling was also noted. Floral visitors were documented and any incidence of herbivory damage was recorded.

\section{Biotic and abiotic habitat features \\ Association with vegetation}

If the base of a shrub occurred within a $15 \mathrm{~cm}$ radius from an $E$. susannae plant, it was classified as being undershrub (US). If the bottom of the shrub fell outside this radius, but branches were projecting over the canopy of the individual, it was classified as shaded by shrub (SS). If no vegetation occurred within the radius and there were no overhanging branches, the individual was classified as growing in the open $(\mathrm{O})$.

\section{Soil sampling and analyses}

Soil samples were taken from five sites, two on the edges of the species distribution and three on the core. Five samples were collected from different patches of plants at each location to a depth of $12-15 \mathrm{~cm}$ per site and pooled.

Exchangeable cations $(\mathrm{Ca} 2+, \mathrm{Mg} 2+, \mathrm{K}+, \mathrm{Na}+)$ were extracted by adding $50 \mathrm{ml} 1 \mathrm{M}$ ammonium acetate $(\mathrm{NH} 4 \mathrm{C} 2 \mathrm{H} 3 \mathrm{O} 2)(\mathrm{pH}=7)$ to $5 \mathrm{~g}$ of soil, shaken for $15 \mathrm{~min}$, and then solution filtered through Whatman 40 filter paper. Extracts were analyzed by atomic absorption spectroscopy (SpectrAA 250 Plus). Soil pH was determined with a 1:2.5 extraction to the solution using deionized water and 1 $\mathrm{mol} / \mathrm{L}$ potassium chloride $(\mathrm{KCl})$ and measured with a digital $\mathrm{pH}$ meter. Particle size distribution was analyzed according to procedures prescribed by the Non-Affiliated Soil Analysis Work Committee (1990). After hydrating 50 $\mathrm{g}$ of soil to the wetting point, samples were pre-treated with $10 \mathrm{ml}$ hydrogen peroxide ( $\mathrm{H} 2 \mathrm{O} 2)$ to remove soil organic matter before sieving (Jensen et al. 2017).

\section{Mapping}

Population boundary coordinates were imported into GeoCAT (Geospatial Conservation Assessment Tool http://geocat.kew.org/) to calculate EOO and AOO according to the IUCN Red List criteria (Bachman et al. 2011).

Using ArcGIS (v 10.2), population locality data were overlaid with the Western Cape Biodiversity Spatial Plan's Protected Areas (CapeNature 2017), the Ecosystem Threat Status (CapeNature 2016), and the Little Karoo Threatened Ecosystems (EADP 2010) spatial data layers to determine the status and protection levels of ecosystems in which the populations occur.

Distances between localities were measured in Euclidean distance and tabulated to determine the degree of isolation amongst populations. 
Data and statistical analyses

Species distribution modeling

A maximum entropy (MaxEnt) approach to modeling species' geographic distributions was chosen for this study. Itutilizess 'presence-only species occurrence data has been shown to produce robust results with the small sample sizes typical for threatened species (Phillips et al. 2006).

Environmental predictors considered for the model included a set of 19 bioclimatic variables (www.worldclim.org/bioclim) derived from monthly temperature and rainfall values (over the period 19702000) that represent annual trends, seasonality, and extreme or limiting environmental factors (Van Staden et al. 2020; Pradhan and Setyawan 2021). The interpolationderived bioclimatic variables are reported not to be devoid of redundancy. Therefore the bioclimatic variables, along with vegetation, and SRTM Digital Elevation Model, slope and aspect (both derived from the DEM), were tested for correlation $(\mathrm{r} 2>-0.65$ or $>0.65)$ using the Band Collection Statistics tool in ArcMap (Merow et al. 2013; Pradhan 2016). The eleven least correlated predictor variables were then selected for use in the models.

Species niches and distributions were modeled with MaxEnt software (v 3.4.1). To train the model, $80 \%$ of presence data were used, while the remaining $20 \%$ were used for accuracy testing. The regularisation multiplier was set to 1 to prevent over-fitting. Model replications were set to 100 using a subsample, and the random seed was set to true. Model performance was evaluated by examining the probability that a randomly chosen presence site is ranked above a random background site (Phillips et al. 2006). An arbitrary ranking will return an Area Under Curve (AUC) of 0.5 , while a perfect order would achieve an AUC of 1 . A jacknife test was applied to provide estimates of the relative contributions made by the environmental variables to the model.

As the model-predicted presence will usually be larger than the species' realized (or actual) distribution (Phillips et al. 2006), model results were refined by converting to binary output (average result from 100 model replications) using the "10 percentile training presence logistic threshold" and excluding highly altered habitats mapped within the 2013-14 South African National Landcover dataset (DEA 2015).

\section{Relationship between population size and density}

Linear regressions were performed in XLSTAT (v 19.6) to explore the relationship between population size and density.

\section{Population structure and regeneration potential}

Only populations for which sufficient reproductive data (fruits and cyathia) were available were used to delimit classes, and resulting size class distributions were then applied to all other populations. Following Condit et al. (1998), expanding size class widths were utilized. Juveniles and sub-adults of E. susannae are single-stemmed, and therefore canopy area was used to describe population structure instead of a number of stems.
Life stage classes were considered to ensure that size classes would be biologically meaningful (Cousins et al. 2014). The seedling life stage was defined as a plant reliant on the cotyledons (seed leaves), and once it switches to external nutrient sources, it was considered to have passed to the juvenile stage (Cousins et al. 2014). Juveniles were defined as non-reproductive plants, with the transition phase to sub-adult being marked by the onset of flowering (Harris et al. 2014). No plants with cotyledons were observed in the field. Therefore all non-reproductive plants were classified as juveniles. Sub-adults were defined as plants occupying the size class displaying intermediate reproduction levels, i.e., where the proportion of nonreproductive individuals outweighed or equaled the proportion of reproductive plants (Cousins et al. 2014). Adult classes were characterized as those where the vast majority $(>85 \%)$ of plants were reproductive. Size class distributions (SCDs) based on canopy area were delimited as follows: juveniles $(\leq 5 \mathrm{~cm} 2)$, sub-adults $(6-20 \mathrm{~cm} 2)$ and adults (21-100, 101-180, 181-260, 261-340, > $340 \mathrm{~cm} 2)$.

To assess population stability, quotients between successive size classes were calculated. Quotients in a stable population will approach an approximately constant value, while fluctuating quotients characterize unstable or episodically recruiting populations.

Population structure was further analyzed in terms of SCD slopes. Since size classes varied in width, the number of plants in each size class was divided by the width of the size class to obtain a corrected abundance per size class (Ni) (Condit et al. 1998), and because some classes contained no individuals, each class was transformed by $\ln (N i+1)$. The least-squares linear regression was performed using the corrected abundance per size class $(\ln [N i+1])$ as the dependent variable and the size class midpoint $(\ln [d i])$ as the independent variable (Condit et al. 1998; Cousins et al. 2014). Interpretation of the shape of SCDs follows Van der Merwe and Geldenhuys (2017). A negative slope indicates fewer individuals in larger size classes (good recruitment), while positive slopes indicate poor recruitment with more individuals in the larger size classes. According to Van der Merwe and Geldenhuys (2017), species with shrinking populations (decreasing plant density) will have less harmful SCD slopes, while growing populations display more negative slopes. The y-intercept of regressions is also reported as it is considered a helpful parameter for understanding population dynamics. A value near zero indicates the presence of a few small individuals. In contrast, a high value is indicative of the occurrence of many small individuals (Van der Merwe and Geldenhuys 2017).

Simpson's index of dominance $(\lambda)$ provides an additional measure of population structure and describes the probability that any two plants from a population are from the same class. Lambda $(\lambda)$ values close to zero indicate that individuals are relatively evenly distributed among the size classes. In contrast, values more relative to 1 show a higher likelihood that two individuals drawn at random belong to the same size class (Cousins et al. 2014). 


$$
\lambda=\frac{1}{N(N-1)} \sum_{i=1}^{k} N_{i}\left(N_{i}-1\right)
$$

Where: $N$ is the total number of plants, $N_{i}$ is the number of plants in class $i$, and $k$ is the number of size classes.

Finally, linear regressions were constructed to explore the relationship between the size of reproductive plants and the number of reproductive structures produced. All data were tested for normality (Shapiro-Wilk W test) before analysis and subjected to logarithmic transformation $(\log 10 y+1)$ when $p<0.05$. To compare plant size and reproductive output between populations, one-way ANOVAs were performed in Statistica v.13.3. Since data violated the assumption of homogeneity, unequal $N$ HSD Post-Hoc Tukey tests were applied to establish statistically significant differences between populations.

\section{RESULTS AND DISCUSSION}

\section{Distribution and threat status}

Euphorbia susannae appeared to be confined to eight sub-populations along the northern foothills of the Langeberg. The distance between the most easterly and westerly populations was a mere $32 \mathrm{~km}$. A length of only $0.1 \mathrm{~km}$ separated two subpopulations (CE1 and CE2). They likely constituted a single population historically before it became fragmented by constructing a dirt road and other infrastructure. One was situated in a game camp on private land, while the other was within an unmanaged provincial nature reserve. Since the two localities were subject to differing management, the subpopulations were considered separately (Figure 4). A small number of solitary, widely scattered individuals (16) were also found during reconnaissance surveys but could not be connected to a larger population (S; Figure 4).

Population sizes varied considerably (Table 2). Three populations in the geographical core area had 300+ individuals, which translated into high plant densities, while populations at the edges of the distribution range were much smaller. It could not, however, be concluded with any degree of certainty that the species conform to the abundant center hypothesis (Dixon et al. 2013) since the populations on the edges (at E and W1; Figure 4) were situated adjacent to main roads, which made them easily accessible, and plant numbers could have been depleted by illegal collection in the past. The bimodal peak of abundance and density observed for central populations CE1, CE2, CW1, and CW2 (Figure 4) appeared instead to conform with a 'peak and tail' type of spatial abundance structure, which posited that several (up to five) high abundance areas (that taper off into 'tails' of lower abundance) might exist across a species' distribution range (Dixon et al. 2013).

GeoCAT results indicated $E$. susannae to be a highly range-restricted species (EOO $170 \mathrm{~km} 2$ and AOO $36 \mathrm{~km} 2$ ). Both measures fit the IUCN category for an Endangered species. If the 31 plants at $\mathrm{E}$ and the nine plants at $\mathrm{W} 1$ (edge populations) became extirpated, the resultant EOO and AOO would qualify the species for the Critically Endangered category. The status of these outlying plants should be considered in future re-assessments of the species' type of threat. Reintroduction of plants at these localities would serve to decrease the species' extinction risk. Population sizes are small, and only approximately 1845 plants remain in the wild. Nevertheless, the species still appeared to qualify for the Endangered category, though with amended qualifying criteria of B1ab(iii, iv, v)+2ab(iii, iv,v). The main threat to the species seems to be habitat degradation based on observations made in the field, although only parts of the distribution range were affected. Plants on the distribution edges at E and W1 and those occurring in unfenced areas may be subject to opportunistic collecting by hobbyists or for the succulent trade, as it was known that individuals had been removed from these areas before (J.H. Vlok, pers. obs.). Only the CE1 sub-population occurred within a protected area (local nature reserve). W1, CW1, and part of the CW2 occurred in threatened vegetation units that were completely unprotected. In contrast, all other localities occurred in vegetation types that enjoyed some level of protection or were not of conservation concern (Table 3 ).

\section{Habitat profile}

\section{Abiotic habitat preferences}

The altitudinal range of $E$. susannae ranged between $376 \mathrm{~m}$ and $495 \mathrm{~m}$ above sea level, with populations mainly inhabiting very gentle slopes $\left(0.5-5^{\circ}\right)$ and sometimes gentle slopes $\left(5-8.5^{\circ}\right)$ (Table 3$)$. The majority of E. susannae plants were located in eastern aspects. Mean annual precipitation over the species' distribution ranges from 369 $\mathrm{mm}$ to $418 \mathrm{~mm}$, with populations at the edges of the content receiving slightly less rainfall than those at the core. Locally, the species preferred Quartz Asbosveld and Quartz Gannaveld habitat types (Vlok et al. 2005) (Table 3). At CW2, a section of the population was situated on top of a ridge extending into Sandolienveld (Vlok et al. 2005), an atypical habitat for the species.

The S-values (quantity of the cations provided by the soil relevant for plant nutrition) of soil samples collected at CW1 and CE2 indicated higher fertility than at other localities. Those were also better supplied with calcium and potassium (Table 4). Overalls, the soil chemistry seemed quite variable. Populations to the east of the distribution range seem to occur on more acidic soils. Soil texture was uneven, with soil at CW2 and W2 being loamy sand, while at E, CE2, and CW1 found to be silty loam. 
Table 2. Plant abundance and density estimated mortality levels and area occupied by surveyed Euphorbia susannae in the western Little Karoo, Western Cape. The small populations on the edges (E and W1) and scattered individuals (S) were counted, and no other measurements were taken. Mean Euclidean distances $(\mathrm{km})$ for each Euphorbia susannae locality from others indicate the degree of isolation. $(\mathrm{C}=$ core $; \mathrm{E}=$ east; $\mathrm{W}=$ west $)$

\begin{tabular}{|c|c|c|c|c|c|}
\hline Locality & $\begin{array}{c}\text { No. of } \\
\text { individuals }\end{array}$ & $\begin{array}{l}\text { Mortality levels } \\
\text { (\% of plants) }\end{array}$ & Area (ha) & $\begin{array}{c}\text { Density } \\
\text { (plants/ha) }\end{array}$ & $\begin{array}{c}\text { Mean isolation } \\
\text { distance }(\mathbf{k m})\end{array}$ \\
\hline CE2 & 605 & 4 & 11.30 & 53.54 & 10.01 \\
\hline CW1 & 403 & 3 & 6.28 & 64.17 & 9.71 \\
\hline CE1 & 370 & 13 & 9.74 & 37.99 & 10.16 \\
\hline CW2 & 299 & 1 & 14.72 & 20.31 & 9.14 \\
\hline W2 & 63 & 0 & 2.05 & 30.73 & 22.14 \\
\hline $\mathrm{C}$ & 49 & 6 & 2.99 & 16.39 & 9.43 \\
\hline $\mathrm{E}$ & 31 & - & - & - & 13.43 \\
\hline W1 & 9 & - & - & - & 24.29 \\
\hline $\mathrm{S}$ & 16 & - & - & - & - \\
\hline Total individuals & 1845 & & & & \\
\hline
\end{tabular}

Table 3. Vegetation and habitat types, status and protection levels of ecosystems, and climatic and topographical conditions associated with surveyed Euphorbia susannae localities (from east to west) in the western Little Karoo, Western Cape. CR, critically endangered; VU, vulnerable; LT, least threatened. 'Vygie' refers to iceplants (Aizoaceae); 'Veld' refers to vegetation; 'Asbos' refers to Pteronia incana (Burm.) DC.; 'Ganna' refers to Salsola aphylla L.f.; 'Sandolien' refers to Dodonaea viscosa (L.) Jacq.; MAP = Mean annual precipitation; MAT = Mean annual temperature.

\begin{tabular}{|c|c|c|c|c|c|c|c|c|c|}
\hline Locality & $\begin{array}{l}\text { Vegetation types } \\
\text { (Mucina et al. 2006) }\end{array}$ & $\begin{array}{l}\text { Habitat types } \\
\text { (Vlok et al. 2005) }\end{array}$ & $\begin{array}{l}\text { Ecosyste } \\
\text { m status }\end{array}$ & $\begin{array}{l}\text { Protection } \\
\text { level }\end{array}$ & $\begin{array}{l}\text { MAP } \\
(\mathbf{m m})\end{array}$ & $\begin{array}{c}\text { MAT } \\
\left({ }^{\circ} \mathbf{C}\right)\end{array}$ & $\begin{array}{c}\text { Altitudinal } \\
\text { range (m) }\end{array}$ & $\begin{array}{c}\text { Slope } \\
\text { (degrees) }\end{array}$ & Aspect \\
\hline$\overline{\mathrm{E}}$ & $\begin{array}{l}\text { Little Karoo Quartz } \\
\text { Vygieveld }\end{array}$ & Quartz Gannaveld & VU & $\begin{array}{l}\text { Partially } \\
\text { protected }\end{array}$ & 403 & 16.2 & $376-378$ & $0.46-0.96$ & $\mathrm{~N}$ \\
\hline CE1 & $\begin{array}{l}\text { Little Karoo Quartz } \\
\text { Vygieveld }\end{array}$ & Quartz Gannaveld & VU & $\begin{array}{l}\text { Partially } \\
\text { protected }\end{array}$ & 407 & 16.0 & $409-436$ & $0.81-6.50$ & $\mathrm{NE}, \mathrm{E}$ \\
\hline CE2 & $\begin{array}{l}\text { Little Karoo Quartz } \\
\text { Vygieveld }\end{array}$ & $\begin{array}{l}\text { Quartz Asbosveld } \\
\text { Quartz Gannaveld }\end{array}$ & $\begin{array}{l}\text { CR } \\
\text { VU }\end{array}$ & $\begin{array}{l}\text { Target met } \\
\text { Partially } \\
\text { protected }\end{array}$ & 412 & 16.0 & $410-441$ & $0.41-4.69$ & SE, E \\
\hline $\mathrm{C}$ & $\begin{array}{l}\text { Little Karoo Quartz } \\
\text { Vygieveld }\end{array}$ & Quartz Asbosveld & $\mathrm{CR}$ & Target met & 407 & 16.1 & $417-426$ & $2.06-2.70$ & $\mathrm{NE}$ \\
\hline \multirow[t]{2}{*}{ CW2 } & $\begin{array}{l}\text { Little Karoo Quartz } \\
\text { Vygieveld }\end{array}$ & Quartz Asbosveld & VU & Unprotected & 418 & 15.7 & $432-495$ & $0.56-8.5$ & $\mathrm{~W}, \mathrm{NE}$ \\
\hline & $\begin{array}{l}\text { Montagu Shale } \\
\text { Renosterveld }\end{array}$ & Sandolienveld & $\mathrm{LT}$ & Unprotected & & & & & \\
\hline CW1 & $\begin{array}{l}\text { Little Karoo Quartz } \\
\text { Vygieveld }\end{array}$ & Quartz Asbosveld & VU & Unprotected & 412 & 16.2 & $406-425$ & $1.44-5.25$ & NE \\
\hline S & $\begin{array}{l}\text { Little Karoo Quartz } \\
\text { Vygieveld }\end{array}$ & Quartz Asbosveld & VU & Unprotected & 410 & 16.1 & $399-443$ & $1.71-3.35$ & NW, SE \\
\hline W2 & Western Little Karoo & $\begin{array}{l}\text { Boerboonleegte } \\
\text { Gannaveld }\end{array}$ & LT & Unprotected & 369 & 16.5 & 384-399 & $2.76-3.91$ & SE \\
\hline W1 & $\begin{array}{l}\text { Little Karoo Quartz } \\
\text { Vygieveld }\end{array}$ & Quartz Apronveld & VU & Unprotected & 400 & 16.6 & $427-431$ & $0.78-1.19$ & $\mathrm{~N}$ \\
\hline
\end{tabular}

Table 4. Soil properties of selected Euphorbia susannae populations (from east to west). S-value, Sum of exchangeable alkaline cations.

\begin{tabular}{|c|c|c|c|c|c|c|c|c|c|c|c|c|c|c|c|}
\hline \multirow{3}{*}{ Locality } & \multicolumn{4}{|c|}{ Nutrient status } & \multicolumn{4}{|c|}{ Exchangeable cations } & \multirow{3}{*}{ S-Value } & \multicolumn{4}{|c|}{ Particle size distribution $(\%)$} & \multicolumn{2}{|c|}{ pH } \\
\hline & $\mathbf{C a}$ & Mg & $\mathbf{K}$ & $\mathbf{N a}$ & $\mathbf{C a}$ & Mg & $\mathbf{K}$ & \multirow[t]{2}{*}{$\mathbf{N a}$} & & Gravel & Sand & Silt & Clay & \multirow{2}{*}{$\mathrm{H}_{2} \mathrm{O}$} & \multirow{2}{*}{$\mathrm{KCl}$} \\
\hline & \multicolumn{4}{|c|}{ (mg/kg) } & \multicolumn{3}{|c|}{$(\mathrm{cmol}(+) / \mathrm{kg})$} & & & $(>2 \mathrm{~mm})$ & & $<2 \mathrm{~mm}$ & & & \\
\hline $\mathrm{E}$ & 506 & 389 & 176 & 121 & 2.52 & 3.2 & 0.45 & 0.52 & 6.7 & 2.1 & 59.1 & 26.7 & 14.1 & 6.71 & 5.81 \\
\hline CE2 & 1244 & 308 & 193 & 71 & 6.21 & 2.53 & 0.49 & 0.31 & 9.54 & 14.5 & 56.3 & 26.9 & 16.7 & 5.88 & 5.25 \\
\hline CW2 & 156 & 44 & 56 & 30 & 0.78 & 0.36 & 0.14 & 0.13 & 1.41 & 6.4 & 77.6 & 11.5 & 10.8 & 4.96 & 3.97 \\
\hline CW1 & 1761 & 536 & 203 & 671 & 8.79 & 4.41 & 0.52 & 2.92 & 16.64 & 6.2 & 53.9 & 28.4 & 17.8 & 7.44 & 7.17 \\
\hline W2 & 743 & 255 & 146 & 161 & 3.71 & 2.09 & 0.37 & 0.7 & 6.88 & 9.6 & 73.9 & 17.3 & 8.8 & 7.28 & 6.75 \\
\hline
\end{tabular}




\section{Species distribution model}

MaxEnt Model performance was very high with an average test AUC score of $0.998 \pm 0.001$ for 100 replicate runs. Vegetation type was the most critical environmental parameter influencing the predicted distribution of the species (Table 5), followed by mean precipitation of the driest month. The first five variables accounted for $96.7 \%$ of the model. Vegetation type, which incorporates geology for mapping purposes (Vlok et al. 2005), overly predominated as other environmental parameters' influence was negligible. This suggests geology be an essential habitat requirement for the species. This plant-geology association is well known for quartz patches in the Succulent Karoo (Curtis et al. 2013). The model predicted a total area of 3811 ha $(38.11 \mathrm{~km} 2)$ as being a potentially suitable habitat, which was very close to the AOO calculated for the species $(36 \mathrm{~km} 2)$ and would be immensely useful for identifying new sites for reintroduction of the species (Ardestani et al. 2015) as the model considered the main bioclimatic and geological factors associated with the distribution of endemic species
(Van Staden et al. 2020). Agricultural activities have irreversibly transformed 251 ha $(6.64 \%)$ of the predicted suitable habitat (Figure 4).

Table 5. Estimate of the relative contributions of environmental variables to the Maxent model for Euphorbia susannae. Values shown are averages of over 100 replicate runs.

\begin{tabular}{lc}
\hline \multicolumn{1}{c}{ Variable } & $\begin{array}{c}\text { Percent } \\
\text { contribution }\end{array}$ \\
\hline Little Karoo vegetation types (Vlok et al. 2005) & 78.7 \\
Mean precipitation of driest month (Bio14) & 9.3 \\
Mean diurnal temperature range (Bio2) & 4.1 \\
Mean temperature of driest quarter (Bio9) & 2.4 \\
Slope & 2.2 \\
Aspect & 1.1 \\
Mean temperature of coldest quarter (Bio11) & 0.7 \\
Mean temperature of wettest quarter (Bio8) & 0.9 \\
Isothermality (Bio3) & 0.4 \\
Mean temperature of warmest quarter (Bio10) & 0.1 \\
Mean precipitation of wettest month (Bio13) & 0.1 \\
\hline
\end{tabular}

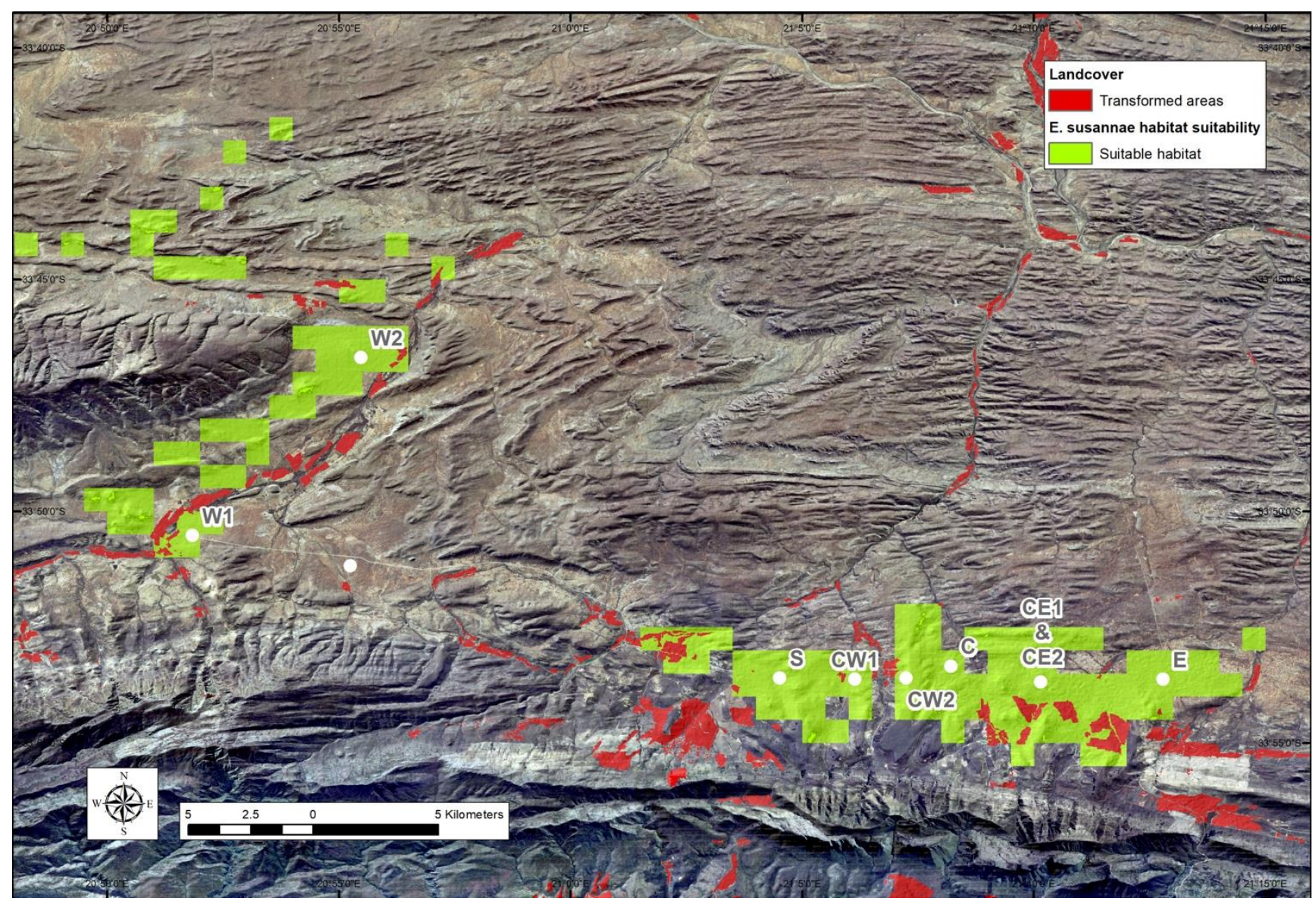

Figure 4. Species distribution model output for Euphorbia susannae displaying potentially suitable habitat (light green). Red areas represent habitats that agricultural activities have transformed. Known populations are indicated with labeled white markers $(\mathrm{S}$ represents the midpoint of the area occupied by scattered individuals). The unlabelled marker indicates the approximate location of a site that could not be accessed to verify the presence of E. susannae 


\section{Biotic interactions}

Three-quarters of E. susannae plants were found to be growing in the shade (Figures 5; 6. A-B). While they sometimes occurred in open quartz patches (Figure 6c), they were more often shaded by shrubs growing around the edges of quartz patches. Euphorbia susannae frequently co-occurred with the succulent Haworthia arachnoidea (L.) Duval beneath nurse shrubs, particularly Dicerothamnus rhinocerotis (L.f.) Koek. Where plants grew in the open amongst quartz (Figure 6. C), they were sunken to a much greater degree than those shaded plants (Figure 6. A-B).

The large percentage of individuals closely associated with surrounding vegetation and rock cover indicated the importance of nurse objects for recruitment and regeneration in these species. In arid environments, nurse plants modify microclimatic conditions beneath their canopies, thus ameliorating abiotic stress, facilitating germination and establishment of seedlings under them, and promoting seedling survivorship (Filazzola and Lortie 2014; Vlok and Schutte-Vlok 2015). These benefactors provide refuge to the most vulnerable life stages of the beneficiaries by regulating soil temperatures, reducing evapotranspiration rates, improving soil properties through the input of organic material, and providing a degree of protection against herbivory (Lu et al. 2017). Additionally, branched structures that transmit wind, such as the canopy of a shrub, are efficient at combing non-rainfall atmospheric moisture from the air (Gurera and Bhushan 2020), and plants growing beneath these shrubs could also benefit from the moisture that is channeled down to the soil around the base. Abiotic nurse objects such as rocks or stones may also provide sufficient micro-relief to facilitate recruitment in open spaces (Filazzola and Lortie 2014; Conver et al. 2020).

The occurrence of succulents preferentially located beneath shrub canopies is reported for all leaf- and stem- succulent plant families of southern Africa, except the Mesembryanthemaceae and Zygophyllaceae (Milton et al. 1999). However, it is essential to note that not all nurse plants serve as equally suitable safe sites for seedling establishment and that beneficiary species may show a preference for a specific set of facilitator species (Vlok and Schutte-Vlok 2015). Thus, further examination of the possible existence of such species-specific facilitative interactions may be warranted for the study species, as declines in suitable nurse plants could potentially negatively affect population recruitment.

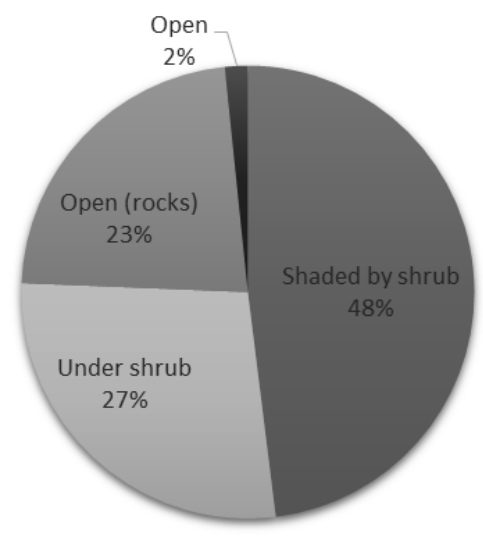

Figure 5. Microhabitat of sampled Euphorbia susannae plants. Under shrub: base of shrub occurred within a $15 \mathrm{~cm}$ radius around E. susannae plant; Shaded by shrub: shrub base $>15 \mathrm{~cm}$ away but branches projecting over E. susannae individual; Open (rocks): no vegetation, but quartz rocks or stones within a $15 \mathrm{~cm}$ radius around E. susannae plant; Open: growing on bare ground with no cover.
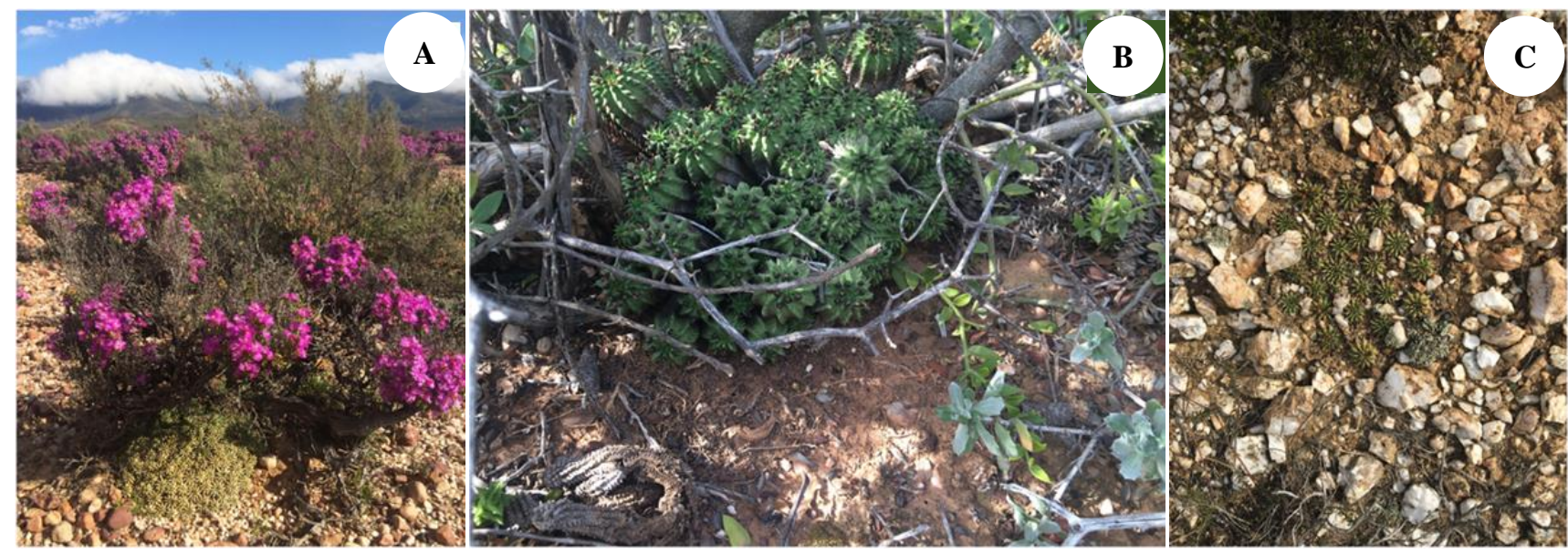

Figure 6. Visual examples of the microhabitat preferences of Euphorbia susannae: (a) Shaded by shrub; (b) Under shrub; (c) Open (rocks). 

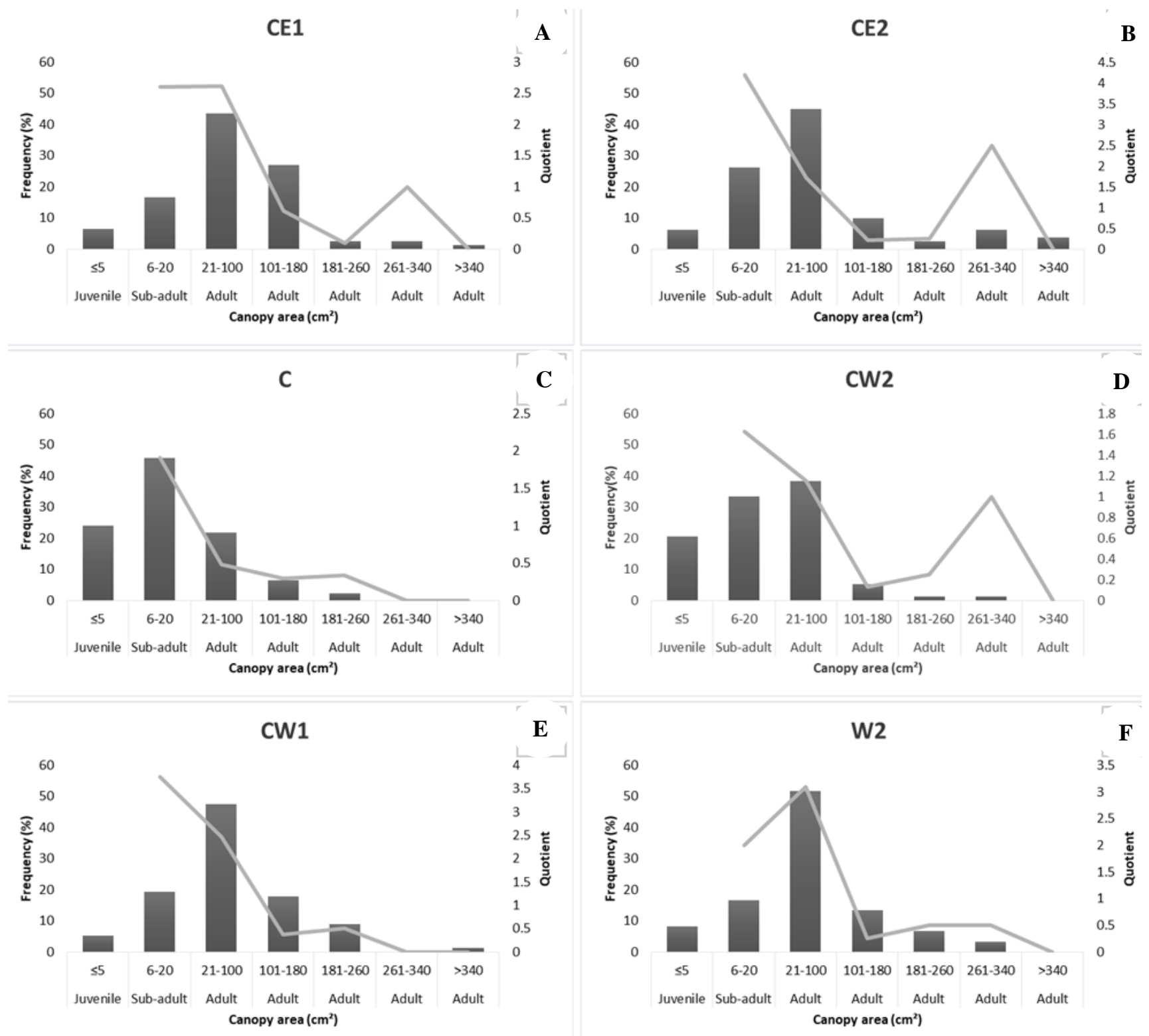

Figure 7. Size class distributions of Euphorbia susannae populations (from east to west). Quotients between successive size classes are also given as a solid line

Table 6. Summary of size class distributions for Euphorbia susannae populations (from east to west). Ordinary least squares regression slopes (with standard error and p values), y-intercept, and Simpson's Index of Dominance (SDI) results are presented. (*significant $\mathrm{p}<0.05 * *$ highly significant $\mathrm{p}<0.005)$

\begin{tabular}{lcccccc}
\hline \multicolumn{1}{c}{ Locality } & Slope & SE Slope & $\mathbf{r}^{\mathbf{2}}$ & $\boldsymbol{p}$ & y-intercept & SDI $(\boldsymbol{\lambda})$ \\
\hline CE1 & -0.149 & 0.021 & 0.927 & $0.002^{* *}$ & 0.396 & 0.287 \\
CE2 & -0.173 & 0.043 & 0.800 & $0.016^{*}$ & 0.450 & 0.282 \\
C & -0.268 & 0.034 & 0.941 & $0.001^{* *}$ & 0.619 & 0.302 \\
CW2 & -0.322 & 0.024 & 0.978 & $<0.001^{* *}$ & 0.756 & 0.295 \\
CW1 & -0.135 & 0.029 & 0.844 & $0.010^{*}$ & 0.366 & 0.291 \\
W2 & -0.146 & 0.011 & 0.978 & $<0.001^{* *}$ & 0.373 & 0.314 \\
\hline
\end{tabular}


The vast majority of floral visitors observed for this species were ants (Hymenoptera; 86\%), followed by beetles (Coleoptera; 7\%) and flies (Diptera; 7\%). Plants in arid environments with flowers with accessible nectaries located close to the ground have a high probability of being visited and pollinated by ants (Rostás et al. 2018). Levels of herbivory were deficient for $E$. susannae, with the highest levels observed at one site being only $3 \%$ of plants. Some plants, particularly those growing in the open, displayed slight damage to the tubercles' tips, possibly due to trampling by the cattle present at some localities. Euphorbia susannae is not generally grazed upon, probably due to the hollow nature of plants between rocks in the open and the inaccessibility of plants growing under nurse shrubs.

Euphorbia susannae employs a ballistic seed dispersal mechanism that scatters seeds within 0.6-2.5 m from the parent plant (Narbona et al. 2016). Many plants in arid environments have evolved toward proxichory (short dispersal distance) (Pueyo et al. 2008). It has been suggested that this strategy has a selective advantage over long-distance dispersal in xeric habitats because seedlings have a higher probability of survival close to where the parent plant has survived to reproductive age (Metz et al. 2015). Visual examination of seeds revealed that no elaiosome is present, thus discounting the possibility of myrmecochory (secondary dispersal by ants).

\section{Population structure and regeneration potential}

The smallest adult size class (21-100 $\mathrm{cm} 2$ canopy area) was the largest in every population, except $C$, where subadults $(6-20 \mathrm{~cm} 2)$ were more prevalent (Figure 7). CE1 and CE2 were the only populations with individuals represented in every size class (Figure $7 a$ and b), with larger classes > $260 \mathrm{~cm} 2$ often absent from the other localities. Ratios of male to female plants in all populations were generally well balanced (Figure 8). Sex ratios at CE2 and W2 were most even (close to 50:50), while CE1 and CW1 were slightly male-dominated. The sex ratio calculated for CW2 was skewed towards females (Figure 8).
A predominance of individuals in the first adult-size class could result from pulse recruitment that may have occurred some years ago, likely due to a period of aboveaverage rainfall. The inconstant quotients that fluctuated across populations, but more so at CE1, CE2, and CW2 (Figure 7a, b, and d), further support this proposition as an inconstant quotient is characteristic of episodic recruitment or unstable populations (Venter and Witkowski 2010). Recruitment is episodic in many arid zone plant species, and pulses of population renewal may occur at intervals of years, decades, or even centuries (Milton et al. 1999). Furthermore, recruitment and seedling in arid ecosystems are directly related to rainfall timing and amount, with plant populations requiring sustained high rainfall episodes in successive years to regenerate (Siebert and Dreber 2019).

Although CE1 and CE2 are near one another and experience the same environmental conditions, there were notable differences between the populations. One might expect that the CE1 sub-population would outperform CE2, considering that the former occurred in a nature reserve intended to protect plant species. Yet, recruitment and plant density were lower than at CE2 (Figure 7a and 7b), and the mortality rate higher (Table 2), in fact, higher than at any other population surveyed in this study. Further investigation into the reasons for this is required, though it is likely due to differences in management.

Significant negative SCD slopes were obtained for all populations (Table 6), indicating 5-24\% (Figure 7). Recent recruitment was highest at $\mathrm{C}$ and $\mathrm{CW} 2$ (Figure 7c and d). The preponderance of smaller individuals in these two populations was also reflected in the more negative slopes and higher y-intercept values (Table 6). Simpson's Index of Dominance (SDI) did not vary much between populations. None of the populations had SDI values below 0.1 , revealing size-frequency to be steeper than expected from exponentially declining populations (Venter and Witkowski 2010). However, in all cases, the SDI was in the range of 2.8-3.15, indicating individuals to be unevenly distributed among the size classes (Venter and Witkowski 2010). The higher y-intercept values (Table 6) at this SDI suggested population growth (Van der Merwe and Geldenhuys 2017).

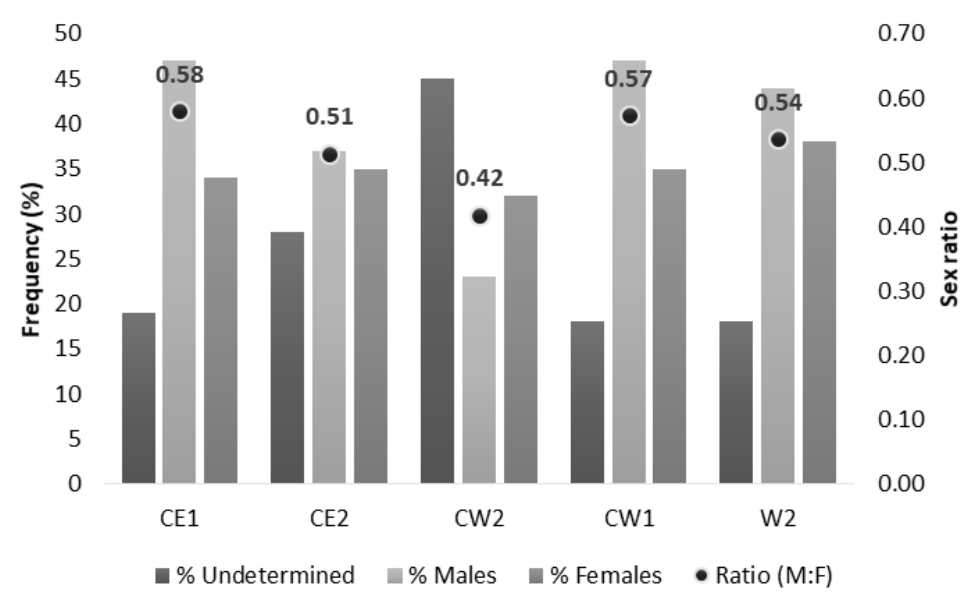

Figure 8. Sex ratio of Euphorbia susannae plants in surveyed populations (males/ (females + males)) following Field et al. (2013). 


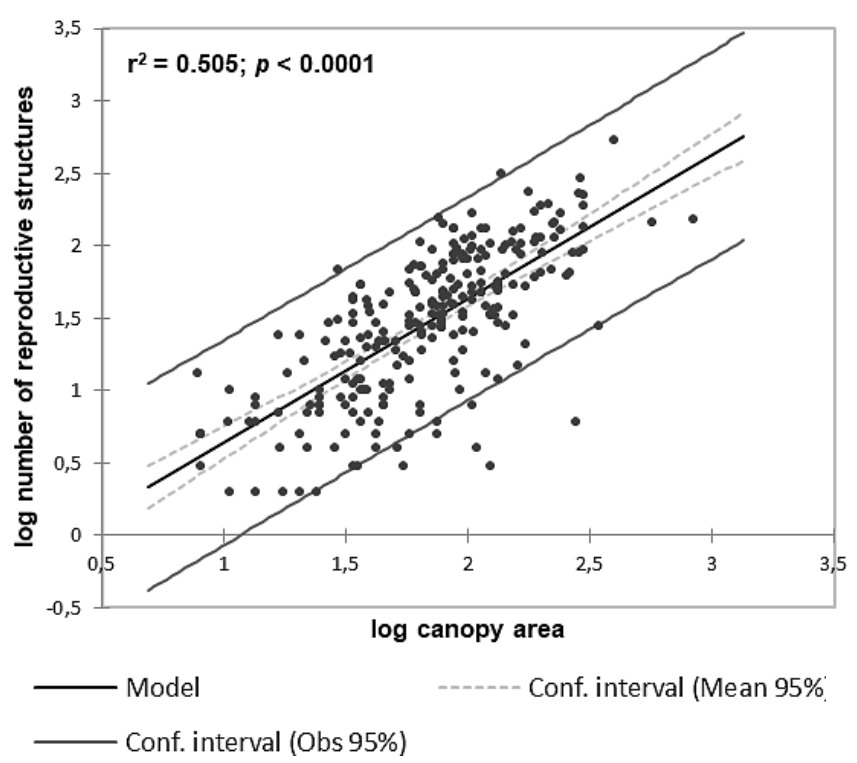

Figure 9. Regression between log plant size (canopy area) and log number of reproductive structures produced by reproductive subadult and adult Euphorbia susannae individuals; all plants for all populations combined

The linear regression of the six largest populations for which densities were available (C, CE1, CE2, CW1, CW2, W2 - see Table 2) revealed a non-significant relationship $(\mathrm{r} 2=0.533 ; p=0.1)$ between population size and plant density for this species. However, there was a significant positive linear relationship between plant size and the number of reproductive structures produced per plant $(\mathrm{r} 2=$ $0.505 ; p<0.001$ ) (Figure 9). Analysis of variance revealed that both mean plant size and reproductive output (mean number of reproductive structures) varied significantly between populations $(p<0.001)$. Pair-wise comparisons showed that plants at CW2 were substantially smaller and produced considerably fewer reproductive systems (Tukey: $p<0.05$ ) than plants in all other populations. Interestingly, soil fertility at $\mathrm{CW} 2$ was lower than in other sites (Table 4).

In conclusion, this study proves that the 1845 individuals and eight sub-populations of $E$. susannae still warrant a Red List status as Endangered. The current distribution of this species is in a narrow band on the northern foot slopes of the Langeberg, and any future habitat transformation and illegal harvesting would cause this species to qualify for a Critically Endangered status. Illegal harvesting has been somewhat alleviated over the last decade by mass exports of over 49,000 E. susannae plants from Canada and the USA to global markets (Jabar 2019). The plants were likely cultivated using tissue culture, as no other propagation method could generate such enormous quantities of plants.

Euphorbia susannae was found to occur in sandy soil on the edges of quartz patches in Asbos- and Gannaveld. The species showed strong dependence on nurse plants to facilitate its recruitment and survival. This suggests that it is vegetation-specific to a large degree and habitat transformation, therefore, poses a significant threat to its survival. In addition, the larger populations with the most individuals all occurred in critically threatened or vulnerable ecosystems and poorly or entirely unprotected.

Currently, the protection level of E. susannae subpopulations is low as its preferred habitat often does not fall within protected areas. Only one subpopulation (approximately $20 \%$ of the total $E$. susannae population based on several individuals) was found to occur within a formally protected area. However, management measures in that nature reserve may not be ideal for the species. Therefore, the results presented here should be incorporated into the Systematic Conservation Planning and Biodiversity Stewardship programs in the Western Cape. In addition, reintroducing plants in low-density edge populations and suitable habitats should be undertaken to improve the conservation status of the species.

The ratios of male to female plants in populations were relatively even. The species regenerates from seed which is dispersed ballistically. Plant growth was noted to be slow, and episodic but healthy recruitment was indicated for most populations. Larger plants showed higher reproductive output. However, it may have been limited by soil fertility.

This study generated a considerable portion of the quantitative data that will allow for the compilation of a comprehensive Non-Detriment Finding for this priority threatened species to assess whether the levels of export are detrimental to its survival or to its role within the ecosystems in which they occur. The data generated will also inform the conservation, management, and sustainable use of the species. Furthermore, this work substantially contributes to the depauperate body of knowledge on the biology and ecology, in general, of threatened euphorbias that are endemic to arid ecosystems in South Africa. 


\section{ACKNOWLEDGEMENTS}

The first author would like to thank the landowners for providing access to their properties and everyone who assisted with fieldwork. Analysis of the soil samples was conducted at the Eco Analytica Laboratory, North-West University. We also thank the SAWS for the provision of climate data. Finally, the financial assistance of the South African National Biodiversity Institute towards this research is at this moment acknowledged. Opinions expressed and conclusions arrived at are those of the author and are not necessarily attributed to SANBI. This study was conducted under permit 0028-AAA0008-00217 issued by CapeNature.

\section{REFERENCES}

Ardestani EG, Tarkesh M, Bassiri M, Vahabi MR. 2015. Potential habitat modeling for reintroduction of three native plant species in central Iran. J Arid Land 7: 381-390. DOI: 10.1007/s40333-014-0050-4

Bachman S, Moat J, Hill AW, de la Torre J, Scott B. 2011. Supporting Red List threat assessments with GeoCAT: Geospatial conservation assessment tool. ZooKeys 150: 117-126 DOI: $10.3897 /$ zookeys. 150.2109

Bertetti D, Pensa P, Poli A, Gullino ML, Garibaldi A. 2012. Podosphaera sp., new causal agent of powdery mildews on Euphorbia perdorfiana, E. susannae (common name Suzanne's spurge), E. inermis and E. aggregate cultivated in Italy. Protezione colture 5: 25-27.

CapeNature. 2016. WCBSP ecosystem threat status [vector] 2016 Western Cape Biodiversity Spatial Plan. http://bgis.sanbi.org/SpatialDataset/Detail/611

CapeNature. 2017. WCBSP protected areas [vector] 2017. Western Cape Biodiversity Spatial http://bgis.sanbi.org/SpatialDataset/Detail/649, accessed on 17.09.2021

CITES. 2012. Assessment of trade in succulent Euphorbia spp. and review of their listing in Appendix II. PC20 Doc. 16.4 Annex 2. https://cites.org/sites/default/files/eng/com/pc/20/E20-16-04-A2.pdf

Condit R, Sukumar R, Hubbell SP, Foster RB. 1998. Predicting population trends from size distributions: A direct test in a tropical tree community. Am Nat 152: 495-509. DOI: 10.1086/286186

Conver JL, Yarwood E, Hetherington LD, Swann DE. 2020. Nurse rock microclimates significantly buffer exposure to freezing temperature and moderate summer temperature. J Arid Environ 177: 104140. DOI: $10.1016 /$ j.jaridenv.2020.104140

Court D. 2010. Succulent Flora of Southern Africa. Struik Nature, Cape Town.

Cousins SR, Witkowski ETF, Pfab MF. 2014. Elucidating patterns in the population size structure and density of Aloe plicatilis, a tree aloe endemic to the Cape fynbos, South Africa. S Afr J Bot 90: 20-36. DOI: 10.1016/j.sajb.2013.09.012

Curtis OE, Stirton CH, Muasya AM. 2013. A conservation and floristic assessment of poorly known species rich quartz-silcrete outcrops within Rûens Shale Renosterveld (Overberg, Western Cape), with taxonomic descriptions of five new species. S Afr J Bot 87: 99-111. DOI: 10.1016/j.sajb.2013.03.017

DEA.2015. National landcover [raster]. Department of Environmental Affairs, Republic of South Africa. http://bgis.sanbi.org/SpatialDataset/Detail/496

Dixon AL, Herlihy CR, Busch JW. 2013. Demographic and population-genetic tests provide mixed support for the abundant centre hypothesis in the endemic plant Leavenworthia stylosa. Mol Ecol 22: 1777-1791. DOI: $10.1111 / \mathrm{mec} .12207$

EADP. 2010. Little Karoo threatened ecosystems 2010 [vector geospatial dataset]. Western Cape Department of Environmental Affairs and Development http://bgis.sanbi.org/SpatialDataset/Detail/448

Filazzola A, Lortie CJ. 2014. A systematic review and conceptual framework for the mechanistic pathways of nurse plants. Global Ecol Biogeogr 23: 1335-1345. DOI: 10.1111/geb.12202
Gurera D, Bhushan B. 2020. Passive water harvesting by desert plants and animals: Lessons from nature. Philos Trans R Soc A 378: 20190444. DOI: $10.1098 /$ rsta.2019.0444

Harris E, Siebert SJ, Smit JHL, Van den Berg J. 2014. Translocation of an endangered succulent plant species from sandstone outcrops earmarked for coal mining. J S Afr I Min Metall 114: 904-912.

IUCN. 2016. Guidelines for using the IUCN Red List categories and criteria v. 12. Prepared by the Standards and Petitions Subcommittee. www.iucnredlist.org/documents/RedListGuidelines.pdf

Jabar L. 2019. Conservation, Management and Sustainable Use of Euphorbia colliculina, E. schoenlandii and E. susannae. [Dissertation]. North-West University, Potchefstroom.

Jensen JL, Schjønning P, Watts CW, Christensen BT, Munkholm LJ. 2017. Soil texture analysis revisited: Removal of organic matter matters more than ever. PLoS ONE 12: e0178039. DOI: 10.1371/journal.pone.0178039

Lu Y, Ranjitkar S, Harrison RD, Xu J, Ou X, Ma X. 2017. Selection of native tree species for subtropical forest restoration in Southwest China. PLoS ONE 12: e0170418. DOI: 10.1371/journal.pone.0170418

Merow C, Smith MJ, Silander Jr. JA. 2013. A practical guide to MaxEnt for modeling species' distributions: What it does, and why inputs and settings matter. Ecography 36: 1058-1069. DOI: 10.1111/j.16000587.2013.07872.x

Metz J, von Oppen J, Tielbörger K. 2015. Parental environmental effects due to contrasting watering adapt competitive ability, but not drought tolerance, in offspring of a semi-arid annual Brassicaceae. J Ecol 103: 990-997. DOI: 10.1111/1365-2745.12411

Milton SJ, Davies RAG, Kerley GIH. 1999. Population level dynamics. In: Dean WRJ, Milton SJ (eds). The Karoo: Ecological Patterns and Processes. Cambridge University Press, New York. DOI: 10.1017/CBO9780511541988.016

Mucina L, Jürgens N, Le Roux A, Rutherford MC, Schmiedel U, Esler KJ et al. 2006. Succulent Karoo biome. In: Mucina L, Rutherford MC (eds). The Vegetation of South Africa, Lesotho and Swaziland. Strelitzia 19. South African National Biodiversity Institute, Pretoria.

Narbona E, Ortiz PL, Arista M. 2016. The possible advantage of myrmecochory in diplochorous species: A test on two Mediterranean Euphorbia species. Plant Biosyst 150(1): 111-120. DOI: 10.3732/ajb.92.3.510

Non-Affiliated Soil Analysis Work Committee. 1990. Handbook of Standard Soil Testing Methods for Advisory Purposes. Vol 160. Soil Science Society of South Africa, Pretoria.

Pfab MF, Witkowski ETF. 1999. Contrasting effects of herbivory on plant size and reproductive performance in two populations of the Critically Endangered species, Euphorbia clivicola R. A. Dyer. Plant Ecol 145: 317-325. DOI: 10.1023/A:1009869011237

Phillips SJ, Anderson RP, Schapire RE. 2006. Maximum entropy modelling of species geographic distributions. Ecol Model 190: 231259. DOI: $10.1016 /$ j.ecolmodel.2005.03.026

Pradhan P. 2016. Strengthening MaxEnt modelling through screening of redundant explanatory bioclimatic variables with variance inflation factor analysis. Researcher 8: 29-34. DOI: 10.7537/marsrsj080516.05

Pradhan P, Setyawan AD. 2021. Filtering multi-collinear predictor variables from multi-resolution rasters of WorldClim 2.1 for ecological niche modeling in Indonesian context. Asian J For 5: 111112. DOI: $10.13057 /$ asianjfor/r050207

Rostás M, Bollmann F, Saville D, Riedel M. 2018. Ants contribute to pollination but not to reproduction in a rare calcareous grassland forb. PeerJ 6: e4369. DOI: 10.7717/peerj.4369

SANBI (South African National Biodiversity Institute). 2014. Scientific authority: Non-Detriment findings. www.sanbi.org/biodiversityscience/science-policyaction/scientific-authority/non-detrimentfindings

Siebert F, Dreber N. 2019. Forb ecology research in dry African savannas: Knowledge, gaps, and future perspectives. Ecol Evol 9: 7875-7891. DOI: $10.1002 /$ ece 3.5307

Smith MJ, Benítez-Díaz H, Clemente-Muñoz MA, Donaldson J, Hutton JM, McGough HN et al. 2011. Assessing the impacts of international trade in CITES-listed species: Current practices and opportunities for scientific research. Biol Conserv 144: 82-91. DOI: 10.1016/j.biocon.2010.10.018

Van der Linde JA, Wingfield MJ, Crous CJ, Six DL, Roux J. 2017. Landscape degradation may contribute to large-scale die-offs of Euphorbia ingens in South Africa. S Afr J Bot 111: 144-152. DOI: 10.1016/j.sajb.2017.03.022 
Van der Merwe H, Geldenhuys C. 2017. Proposed long-term monitoring protocol and applications for Aloidendron dichotomum populations. S Afr J Bot 109: 253-262. DOI: 10.1016/j.sajb.2017.01.008

Van Staden N, Siebert SJ, Cilliers DP, Wilsenach D, Frisby AW. 2020 Floristic analysis of semi-arid mountain ecosystems of the Griqualand West centre of plant endemism, Northern Cape, South Africa. Biodiversitas 21: 1989-2002. DOI: 10.13057/biodiv/d210526

Van Wyk AE, Smith GF. 2001. Regions of Floristic Endemism in Southern Africa: A Review with Emphasis on Succulents. Umdaus Press, Hatfield.

Venter SM, Witkowski ETF. 2010. Baobab (Adansonia digitata L.) density, size-class distribution and population trends between four land-use types in northern Venda, South Africa. For Ecol Manag 259: 294-300. DOI: 10.1016/j.foreco.2009.10.016

Vlok JH, Cowling RM, Wolf T. 2005. A vegetation map for the Little Karoo. Unpublished maps and report for a SKEP project supported by CEPF grant no 1064410304.

Vlok JH, Raimondo D. 2007. Euphorbia susannae Marloth. national assessment: Red List of South African plants version 2020.1. http://redlist.sanbi.org/species.php?species=574-346

Vlok JH, Schutte-Vlok AL. 2015. Plants of the Klein Karoo. $2^{\text {nd }}$ edition. Umdaus Press, Hatfield.

Young AJ, Guo D, Desmet PG, Midgley GF. 2016. Biodiversity and climate change: Risks to dwarf succulents in Southern Africa. J Arid Environ 129: 16-24. DOI: 10.1016/j.jaridenv.2016.02.005 